\title{
THE FORAMEN MAGNUM: A MORPHOMETRIC STUDY ON CT IMAGES OF ADULTS
}

\section{Supriya Garapati ${ }^{1}$, Ch. Santhi ${ }^{2}$, Pentyala Suneetha ${ }^{3}$, Krishna Sahith Reddy.K.V ${ }^{4}$.}

${ }^{1}$ Professor and HOD, Department of Anatomy, ESIC Medical College, Sanath nagar, Hyderabad, Telangana, India.

${ }^{* 2}$ Assistant professor, Department of Anatomy, Narayana Medical College, Nellore, AndraPradhesh, India.

${ }^{3}$ Professor, Department of Radiology, Narayana Medical College, Nellore, AndraPradhesh, India.

${ }^{4}$ Assistant professor, Department of Radiology, Narayana Medical College, Nellore, AndraPradhesh, India.

\section{ABSTRACT}

Objective: The purpose of the present study was to assess the morphometric values of foramen magnum to evaluate sexual dimorphism as well as its clinical importance.

Materials and Methods: The study was conducted on 100 (Male 56, Female 44) CT scans. Morphometric study was conducted on foramen magnum of occipital bone. From all the CT images the foramen magnum anteroposterior diameter and transverse diameter were measured. Area of foramen magnum was calculated automatically. Foramen magnum index was calculated by using the formula $\mathrm{Ht} / \mathrm{Br} \times 100$. The data was statistically analysed.

Results: The mean anteroposterior diameter in males and females was $33.9 \pm 2.78,32.2 \pm 2.24$, the mean transverse diameter in males and females was $27.7 \pm 2.27,26.7 \pm 2.68$ and the area of foramen magnum in males and females was $739.5 \pm 9.96,676.1 \pm 8.76$, index of the foramen magnum in males and females was $82.09 \pm 7.86$, $83.02 \pm 9.55$ respectively

Conclusion: This study concludes that the parameters measured were higher in males compared to females except foramen magnum index. This was noticed higher in females than males.

KEY WORDS: Foramen magnum, Computed tomographic images, Morphometry.

Address for Correspondence: Mrs. Ch. Santhi, Assistant professor, Department of Anatomy, Narayana Medical College, Nellore, AndraPradhesh, India. E-Mail: kota.santhireddy@gmail.com

Access this Article online

Quick Response code

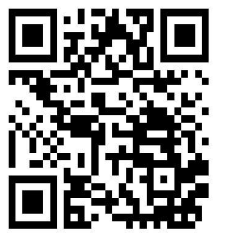

DOI: $10.16965 /$ ijar.2018.144

Journal Information

International Journal of Anatomy and Research

\begin{tabular}{|c|c|} 
ICV for 2016 \\
90.30
\end{tabular}$\quad \begin{gathered}\text { ISSN (E) 2321-4287 | ISSN (P) 2321-8967 } \\
\text { https://www.ijmhr.org/ijar.htm } \\
\text { DOI-Prefix: https://dx.doi.org/10.16965/ijar }\end{gathered}$

Article Information

Received: 13 Feb 2018

Peer Review: 13 Feb 2018

Revised: None
Accepted: 07 Mar 2018

Published (O): 05 Apr 2018

Published (P): 05 Apr 2018

\section{INTRODUCTION}

Foramen magnum is a three dimensional large aperture that lies within the basal region of the occipital bone of the skull $[1,2]$. In any medicolegal investigation, estimation of the sex of the skeletal remains is an essential element [3]. Due to the thickness of the cranial base and its relatively protected anatomical position, this area of the skull tends to withstand both physical insults and inhumation somewhat more successful than many other areas of the cranium [4].several studies conducted in foramen magnum of dry skulls to known the sexual dimorphism. In the present study we aimed at morphometric study of the foramen magnum in CT Scans. 


\section{MATERIALS AND METHODS}

For this analytical study, after taking approval from the institutional ethical committee, we examined 100 computer tomographic images of both sexes (Male 56, Female 44) aged between 18-75. The CT images were collected from department of radiodiagnosis, Narayana general hospital, Nellore, A.P, India.

From each CT film, the foramen magnum anteroposterior diameter (APD) and transverse diameter (TD) were taken in $\mathrm{cms}$. Area of foramen magnum (FMA) was automatically calculated in CT images.

APD: Anteroposterior posterior diameter was measured in midsagittal plane between basion to prosthion [Figure: 1]

TD: Transverse diameter was the distance between the lateral margins of the foramen magnum [Figure: 2]

After measuring APD, TD from each foramen magnum the index of the foramen magnum was calculated by using formula

Foramen magnum index (FMI)

$$
=\frac{\text { Transverse diameter }}{\text { Antero posterior diameter }} \times 100
$$

$\mathrm{FMA}=$ Area of foramen magnum was recorded automatically in CT images

The data acquired from this study were spread in MS Excel (MS office 2010). Mean and standard deviation were calculated. Student $t$ test was performed to know the level of significance at $95 \%$ confidence interval.

\section{RESULTS}

The results of various parameters of the foramen magnum of CT scans were represented in table1.

For the present study we observed the mean anteroposterior diameter in males was $33.9 \pm 2.78$ and in females was $32.2 \pm 2.24$. The transverse diameter in males and females was $27.7 \pm 2.27,26.7 \pm 2.68$ respectively. Area of the FM in males was $739.5 \pm 9.96$ and in females it was noted as $676.1 \pm 8.76$ and the FMI was observed in males and females as $82.09 \pm 7.86$, $83.02 \pm 9.55$

From the evaluation of CT images the anteroposterior and transverse diameters and foramen magnum area were showing higher values in males as compared to those of females. The foramen magnum index was higher in females than males. In our study among all the parameters the anteroposterior diameter and area of the foramen magnum were showing higher statistical significance.

Fig. 1: Showing measuring of APD of Foramen magnum.

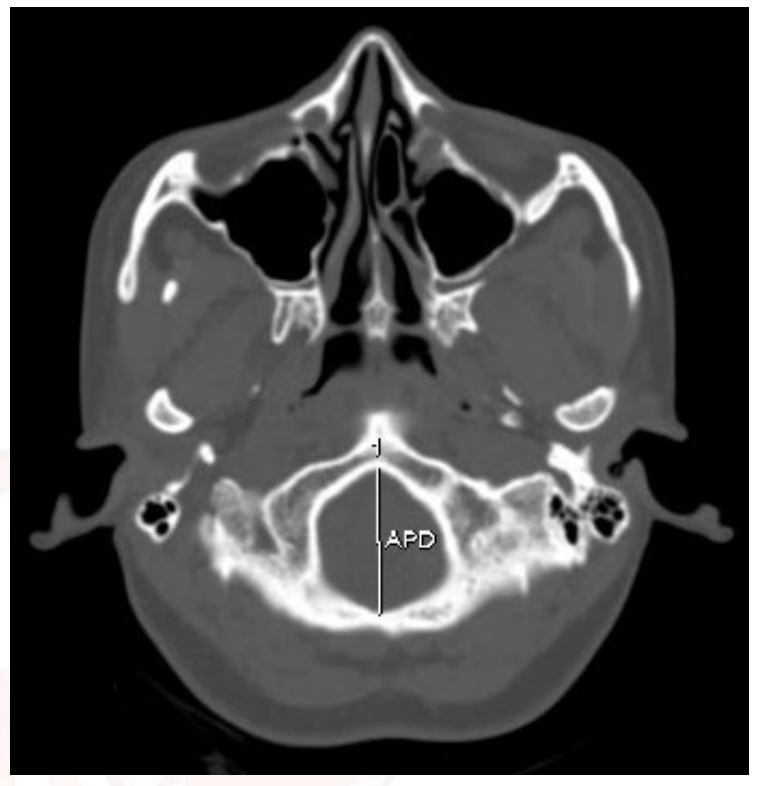

Fig. 2: Showing measurement of TD of Foramen magnum.

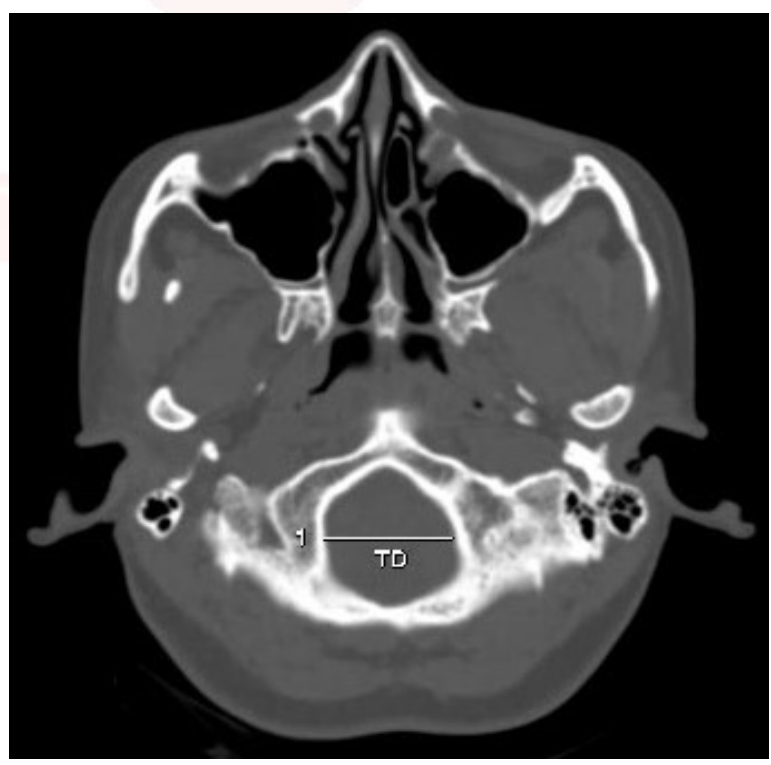

Table 1: Exhibiting morphometric values of foramen magnum in CT scans.

\begin{tabular}{|c|c|c|c|c|}
\hline \multirow{2}{*}{ S.no } & Parameters & \multicolumn{2}{|c|}{ MEAN \pm SD $(\mathrm{Cm})$} & \multirow{2}{*}{ P value } \\
\cline { 3 - 4 } & Male (56) & Female (44) & \\
\hline 1 & $\begin{array}{c}\text { Anteroposterior diameter of } \\
\text { foramen magnum(APD) }\end{array}$ & $33.9 \pm 2.78$ & $32.2 \pm 2.24$ & $0.001^{* * *}$ \\
\hline 2 & $\begin{array}{c}\text { Transverse diameter of foramen } \\
\text { magnum(TD) }\end{array}$ & $27.7 \pm 2.27$ & $26.7 \pm 2.68$ & 0.045 \\
\hline 3 & Area of foramen magnum(FMA) & $739.5 \pm 9.96$ & $676.1 \pm 8.76$ & $0.001^{* * *}$ \\
\hline 4 & Index of foramen magnum(FMI) & $82.09 \pm 7.86$ & $83.02 \pm 9.55$ & 0.527 \\
\hline
\end{tabular}




\section{DISCUSSION}

For Identification of unknown individuals, bones play a key role in medical sciences such as forensic medicine and anthropology. From the entire skeleton the skull and pelvis are the two important sources for identification of sex of which cranium play a major role as it resists decomposition, mutilations, explosions and fire $[5,6]$.

Many researchers worked on dry skulls to evaluate the morphometric parameters and its importance in determining the sex. In the present study we focused on CT scans and the findings obtained from this study were compared with previous authors.

In 2003 Khalial et al [7] conducted a study in CT scans of 110 turkey subjects, in their study they reported the mean anteroposterior diameter in males and females was $37.2 \pm 3.43,34.6 \pm 3.16 \mathrm{~cm}$ and transverse diameter in males was 31.6 \pm 2.99 , and in females it was observed as $29.3 \pm 2.19 \mathrm{~cm}$. Area of foramen magnum in males was 931.7 \pm 144.29 and in females 795.0 \pm 99.32 .

Guptha Chandhini et al [8] reported the mean sagittal diameter in males was $36.46 \pm 3.43 \mathrm{~mm}$ and the mean transverse diameter was $30.53 \pm 2.94 \mathrm{~mm}$. In female the mean sagittal diameter were noted $34.99 \pm 3.2 \mathrm{~mm}$ and the mean transverse diameter was $28.99 \pm 2.53 \mathrm{~mm}$. Foramen magnum area in males was $791.57 \pm 131.27$ and in females 736.81 \pm 130.57 .

A study done by Muralidhar $p$ shepur et al [9] in 30 subjects of equal male and female showed that the mean anteroposterior diameter in male and female was $38.5 \pm 3.6 \mathrm{~mm}, 35.2 \pm 3.1 \mathrm{~mm}$. The mean transverse diameter in male and female was $29.1 \pm 2.3 \mathrm{~mm}$ and $27.6 \pm 2.3 \mathrm{~mm}$ and the area of FM in males was $862.0 \pm 112.0 \mathrm{~mm}$ and in females it was $758.0 \pm 109.0 \mathrm{~mm}$.

By comparing our results with those mentioned above we found that these values were higher than the current study. In our study we recorded the mean anteroposterior diameter in males was $33.9 \pm 2.78$ and in females was $32.2 \pm 2.24$. The transverse diameter in males and females was $27.7 \pm 2.27,26.7 \pm 2.68$ respectively. The FMA in males was $739.5 \pm 9.96$ and in females it was noted as $676.1 \pm 8.76$.
According to the AT Uthmal et al [10] the mean anteroposterior diameter in male and female was $34.9 \pm 2.0 \mathrm{~mm}, 32.9 \pm 2.0 \mathrm{~mm}$. The mean transverse diameter in male and female was $29.5 \pm 2.5 \mathrm{~mm}$ and $27.3 \pm 2.2 \mathrm{~mm}$ and the area of FM in males was $862.0 \pm 112.0 \mathrm{~mm}$ and in females it was $758.0 \pm 109.0 \mathrm{~mm}$. These findings were very close to the present study.

In a study of Suresh Sukumar et al [11] the mean in males was $35.18 \pm 2.84 \mathrm{~mm}$ for anteroposterior diameter and $29.53 \pm 2.76 \mathrm{~mm}$ for transverse diameter. In females the mean was $31.77 \pm 2.05$ and $26.31 \pm 1.15$ respectively. These findings were close to the present study.

In our study foramen magnum index in male skulls was $82.09 \pm 7.86$ and in female skulls was $83.02 \pm 9.55$.These results support prior findings in which the foramen magnum index was found to be higher for the female skulls than for the male skulls (Table: 2$)[12,13]$.

Table 2: Comparison of FMI in male and female skulls of various studies.

\begin{tabular}{|c|c|c|c|c|c|c|}
\hline S.No & Author \& year & $\begin{array}{c}\text { Study } \\
\text { sample }\end{array}$ & Male & Female & $\begin{array}{c}\text { MeantSD } \\
\text { Males }\end{array}$ & $\begin{array}{c}\text { MeantSD } \\
\text { Females }\end{array}$ \\
\hline 1 & Fatma et al 2010 [12] & 54 & 25 & 29 & $83.70 \pm 9.27$ & $84.94 \pm 7.67$ \\
\hline 2 & Lokesh Goyal et al 2016 [13] & 95 & 55 & 40 & $83.04 \pm 6.98$ & $84.66 \pm 6.08$ \\
\hline 3 & Present study 2018 & 100 & 56 & 44 & $82.09 \pm 7.86$ & $83.02 \pm 9.55$ \\
\hline
\end{tabular}

\section{CONCLUSION}

Foramen magnum is an important landmark in the basal region of the cranium because through it significant vital structures transmits i.e. lower end of medulla oblongata along with meninges, vertebral arteries, and the spinal accessory nerve. The knowledge of the FM dimensions are of great interest for clinicians because the key structures pass through it may endure compression in cases of FM achondroplasia, FM brain herniation and helpful for radiological diagnostic procedures (Arnold chiari's syndrome) and for neurosurgeons during performing surgeries in the region of foramen magnum and data of the present study may provide morphometric information to determine sex of an individual in the field of forensic medicine and anthropology.

\section{ABBREVIATIONS}

FM- Foramen magnum

CT - Computer Tomography, APD- Antero posterior diameter, 
TD - Transverve diameter,

FMA - Foramen magnum area,

FMI - Foramen magnum index

\section{Conflicts of Interests: None}

\section{REFERENCES}

[1]. Roma Patel, C D. Mehta. Morphometric Study of Foramen Magnum at the Base of Human Skull in South Gujarat; Journal of Dental and Medical Sciences, 13(6) pp23-25.

[2]. Santhi CH, Lokanadham S, Morphometric Study on Foramen Magnum of Human Skulls, Medicine Science 2013;2(4):792-8.

[3]. T.Vedanayagam, V.Sathyamurthy. Sex Determination from Foramen Magnum Measurements- A Regional Study in Chennai,TN ; Indian Journal of Forensic and Community Medicine,July-September 2015;2(3):179-181.

[4]. Thanuj Kanchan, Anadi Gupta, and Kewal Krishnan. Craniometric Analysis of Foramen Magnum for Estimation of Sex; International Scholarly and Scientific Research\& Innovation 2013;7(7).

[5]. Santhi CH, V.Subhadra Devi, S.Lokanadham, B.Ravindra Kumar.Cranial Index - Sex Determination Parameter of Adult Human Skulls in South Indian Population.IJMPS, 2013;3(11):01-06.

[6]. Anant Dattatray Dhanwate, Dope Santoshkumar Ankushrao. Indian Journal of Clinical Anatomy and Physiology,April-June, 2017;4(2):241-246.
[7]. Murshed KA Cicekcibasi AE,Tuncer I. Morphometric Evaluation of the Foramen Magnum and variations in its shape: Astudy on Compuerized Tomographic Images of Normal Adults. Turkish Journal of Medical Sciences.2003;33(1):301-306.

[8]. Radhakrishnan P, Guptha Chandni, Sandeep Kumar, Antony Sylvan D'Souzal. Amorphometric Analysis of the Foramen Magnum and Variations in its Shape: A Computerized Tomographic Study; Novel Science International Journal of Medical Sciences 2012;1(910):281-285.

[9]. Muralidhar P Shepur, Magi M, Nanjundappa B, Pavan P Havaldar, Premalatha Gopi,shaik Hussain Sahib. Morphometric Analysis of Foramen Magnum. Int J Anat Res. 2014;2(1):249-55.

[10]. Uthman A T, NH AL-Rawi, JF AL Timimi. Evaluation of Foramen Magnum in gender determination using helical CT scaning.Dentomaxillofac Radio. 2012;41 (3):197-202.

[11]. Suresh Sukumar, Sushil Yadav, Manju H B. 3D Reconstruction Computer Tomography of Foramen magnum and Fronto Nasal Junction for Sex Determination in South Indian population. Int J Pharm Bio Sci Oct 2012;3(4):(B)615-619.

[12]. Fatma Hayat Erdil, Vedat Sabancyooullary, Mehmet Cimen Oktay Ibyk: Morphometric analysis of the foramen magnum by computed Tomography: Erciyes Medical Journal;, 2010;32(3):167-170.

[13].Dr.Lokesh Goyal, Dr.Prem Chandra Srivastava, Dr.Sangita Agarwala, Dr. Shikha Saxena, Dr. Jyothi Barwa. Sch.J.App.Med.Sci. 2016; 4(3F):1071-1074.

\footnotetext{
How to cite this article:

Supriya Garapati, Ch. Santhi, Pentyala Suneetha, Krishna Sahith Reddy.K.V.THE FORAMEN MAGNUM: A MORPHOMETRIC STUDY ON CT IMAGES OF ADULTS. Int J Anat Res 2018;6(2.1):5163-5166. DOI: 10.16965/ijar.2018.144
} 